\title{
Phosphorus Fertigation and preplant Conventional Soil Application of Drip Irrigated Grapevines
}

\author{
S.T. Abou-Zied and Amal L. Abd El Latif \\ Soil Sciences Dept., Fac. of Agriculture, Cairo University, Giza, \\ Egypt
}

\begin{abstract}
7 IELD experiment was conducted for two consecutive seasons (2011 and 2012) to compare Grapevine response to conventional soil $\mathrm{P}$ application as triple super phosphate (TSP) and fertigation when $\mathrm{P}$ is applied in the form of phosphoric acid $\left(\mathrm{H}_{3} \mathrm{PO}_{4}\right)$, ammonium polyphosphate (APP) and urea phosphate (UP). Two rates of phosphorus were used, 20 and $40 \mathrm{Kg} \mathrm{P}_{2} \mathrm{O}_{5} /$ fed.
\end{abstract}

Plant and soil samples were collected and analyzed for chemical analysis. The data presented that total soluble solid (T.S.S), leaf petioles $\mathrm{P}, \mathrm{Zn}, \mathrm{Fe}$, yield and $\mathrm{P}$ concentration in soil were higher with $\mathrm{P}$ fertigation than conventional soil $\mathrm{P}$ application and increased with increasing $\mathrm{P}$ rate. While the soil $\mathrm{pH}$ decreased significantly under $\mathrm{P}$ fertigation compared to conventional soil application.

As a source of $\mathrm{P}$ fertigation, the obtained revealed data presented that APP gave the highest T.S.S, leaf petioles $\mathrm{P}, \mathrm{Zn}$, $\mathrm{Fe}$, yield and $\mathrm{P}$ concentration in soil compared with $\mathrm{H}_{3} \mathrm{PO}_{4}$ and UP. While UP gave the lower value of soil $\mathrm{pH}$.

Keywords: Grapevine, Phosphorus, Fertigation, Preplant application.

On worldwide basis, grapes (Vitis vinefera, L) is considered the fourth crop while it ranked the first largest deciduous fruit crop. Egypt ranks on the world production scale as $14^{\text {th }}$ largest producer of grapes. Grapevines are heavily planted in the newly reclaimed areas in Egypt. Grape quality is affected by vineyard conditions; it also depends on management practices such as variety and fertilization. Grape growers in newly reclaimed areas, though, have inadequate information about suitable fertilization rates for vines especially for phosphorus. Such rates are usually added in improper wayes and rates which result in over and under supply, and which is usually associated with poor berry color, irregular and late rippning and low productivity in the following years.

Fertigation enable to control the concentration and composition of various mineral elements in the root zone since plant roots take up nutrients according to concentration gradients rather than to amount per hectar (Bravdo, 2007). 
Jagdev et al. (2008) noticed that fertigation treatments in Thompson seedless grape increased $\mathrm{P}$ fertilizer use efficiency by $73.6 \%$ over the conventional methods of fertilizer application, also fertigation treatments gave higher yield of grape and the greatest nutrient use efficiency. Also, Howell and Conradie (2013) reported that daily fertigation resulted in the accumulation of $\mathrm{P}$ in the leaf petioles of the grapevine.

The purpose of the present research is to examine the response of drip irrigated grapevine to conventional soil $\mathrm{P}$ fertilizer application and fertigation when $\mathrm{P}$ is applied in the form of phosphoric acid, ammonium polyphosphate and urea phosphate.

\section{Material and Methods}

A field experiment was carried out during the two successive seasons (20112012) on one feddan of Thompson seedless grapevines, in a vineyard farm located at El-Sadat City, Menoufiya Governorate. The vines were five years old and spaced at $1.5 \mathrm{~m}$ within vines and $3 \mathrm{~m}$ between rows. The tested vines were grown in sandy soil irrigated by groundwater (EC $0.9 \mathrm{dSm}^{-1}$ and $\left.\mathrm{pH} 7.60\right)$ through drip irrigation system (two lateral lines per row and emitters $50 \mathrm{~cm}$. space of GR type each at $4 \mathrm{Lh}^{-1}$ ). Treatments were carried out in three replicates ( 5 vines in each replicate) arranged in a complete randomized block design in split plot. The sources of phosphorus used in this experiment were:

a- Triple super phosphate $\left[\left(\mathrm{Ca}_{3} \mathrm{PO}_{4}\right)\right.$ (TSP) ]

b. Phosphoric acid $\left(\mathrm{H}_{3} \mathrm{PO}_{4}\right)$

c. Ammonium polyphosphate $\left[\left(\mathrm{NH}_{4}\right)_{3} \mathrm{HP}_{2} \mathrm{O}_{7}+\mathrm{NH}_{4} \mathrm{H}_{2} \mathrm{PO}_{4}(\mathrm{APP})\right]$

d. Urea Phosphate $\left[\mathrm{CO}\left(\mathrm{NH}_{2}\right)_{2} \cdot \mathrm{H}_{3} \mathrm{PO}_{4}(\mathrm{UP})\right]$

The conventional application of $\mathrm{P}$ as triple super phosphate (TSP) was broadcast and incorporated in the top $20 \mathrm{~cm}$ of soil at the beging of season. For the fertigation treatments, $\mathrm{P}$ was applied as phosphoric acid $\left(\mathrm{H}_{3} \mathrm{PO}_{4} 45 \% \mathrm{P}_{2} \mathrm{O}_{5}\right)$, ammonium polyphosphate (APP $52 \% \mathrm{P}_{2} \mathrm{O}_{5}$ and $15 \% \mathrm{~N}$ ) and urea phosphate (UP $44 \% \mathrm{P}_{2} \mathrm{O}_{5}$ and $18 \% \mathrm{~N}$ ). Two rates of phosphorus were used, 20 and $40 \mathrm{Kg}$ $\mathrm{P}_{2} \mathrm{O}_{5} /$ fed. Time of application of phosphorus fertigation was three times/week.

Phosphorus fertilization as fertigation started from the first of March up to $15^{\text {th }}$ of April while the rates of ammonium nitrate and potassium sulphate; $80 \mathrm{~kg}$ $\mathrm{N}$ fed ${ }^{-1}$ and $120 \mathrm{~kg} \mathrm{~K}_{2} \mathrm{O}$ fed $^{-1}$ were applied from first of March up to $15^{\text {th }}$ of June. All treatments were once sprayed with $\mathrm{Fe}$ and $\mathrm{Zn}(1 \mathrm{gm} / \mathrm{L})$. The first application at the bloom stage and the second application was after 15 days from the first application.

Table 1 presents some soil properties of the studied experimental site (0-30 $\mathrm{cm})$ at the begining of season (Klute, 1986).

Egypt. J. Soil Sci. 56, No. 1 (2016) 
PHOSPHORUS FERTIGATION AND PREPLANT CONVENTIONAL SOIL... 43

TABLE 1. some soil properties of the studied experimental site

\begin{tabular}{|l|l|l|c|}
\hline \multicolumn{2}{|c|}{ Particle size distribution $(\mathrm{g} / \mathrm{kg})$} & \multicolumn{2}{c|}{ Chemical analysis } \\
\hline Clay & 47 & $\mathrm{pH}(1: 2.5)$ & 8.0 \\
Silt & 5 & $\mathrm{EC}\left(\mathrm{dS} / \mathrm{m}^{-1}\right)(1: 2.5)$ & 0.34 \\
Fine sand & 228 & $\mathrm{CaCO}_{3}(\mathrm{~g} / \mathrm{kg})$ & 37 \\
Coarse sand & 675 & $\mathrm{O} . \mathrm{M}(\mathrm{g} / \mathrm{kg})$ & 0.6 \\
Texture class & Sandy & Available nutrients & $\mathrm{N} 32$ \\
& & (mg/kg soil) & $\mathrm{P} 4.6$ \\
& & & $\mathrm{~K} 61$ \\
\hline
\end{tabular}

At harvesting , 5 clusters were picked randomly from 5 vines in each replicate to measure average cluster weight ,berry weight , yield = average cluster weight per vine $\mathrm{x}$ number of cluster per vine, TSS, expressed as Brix by using hand refractometer and chemical composition of leaf adjacent to fruit clusters was determined at bloom stage.

Representative blade sample was taken, oven dried at $70^{\circ} \mathrm{C}$, ground and prepared for wet digestion using mixture of sulfuric and perchloric acids (1:1) as described by Cottenie et al. (1982). The digests were then subjected to measurement some nutrients $(\mathrm{P}, \mathrm{Fe}$ and $\mathrm{Zn}$ ) using procedures, according to A.O.A.C., (1990). Phosphorus concentration (\%) in soil before and after fertization.

Soil samples were taken before and after fertilization in the first and last week of fertilization to measure available $\mathrm{P}$ concentration, according to Olsen et al. (1958). Additional soil samples were taken at the end of the trial in the plots underneath the dripper. Soil $\mathrm{pH}$ was determined according to Klute (1986).

The data were statistically analyzed according to the technique of analysis of variance (ANOVA) of randomized complete block design by Gomez and Gomez (1984).

\section{Results and Discussion}

Yield and yield components:

Statistical analysis confirmed differences due to the effect of fertigation and conventional P- application to the soil (Table 2). The highest percentage of fruitfull buds and of cluster weight was recorded for $\mathrm{P}$ fertigation compared to $\mathrm{P}$ conventional application.

With regards to the source of $\mathrm{P}$ fertigation, the results showed that in the first and second seasons APP and UP gave higher fruitfull buds percentage at rate $40 \mathrm{~kg} \mathrm{P}_{2} \mathrm{O}_{5}$ fed $^{-1}$, compared to TSP and $\mathrm{H}_{3} \mathrm{PO}_{3}$. Also, the results showed that, APP and UP gave the higher cluster weight at $40 \mathrm{~kg} \mathrm{P}_{2} \mathrm{O}_{5} \mathrm{fed}^{-1}$, compared to the other sources of $\mathrm{P}$, while there was no significant difference between APP and UP. Also, there was no significant difference between UP and $\mathrm{H}_{3} \mathrm{PO}_{4}$. 
To asses the effect of applied P-rates, there was a significant difference between the two rates in both season. The highest percentage of fruitfull and cluster weight was recorded for vines fertilized with $\mathrm{P}$ rate $40 \mathrm{~kg}_{2} \mathrm{O}_{5}$ fed $^{-1}$, while the lowest value was recorded with $20 \mathrm{~kg} \mathrm{P}_{2} \mathrm{O}_{5} \mathrm{fed}^{-1}$. Similar results were obtained by Ahmed (1991) who studied the effect of NPK fertilization on bud behavior and he found that percentage of fruit full buds raised on Thompson seedless vines by increasing the soil application of NPK. Also, Sidhu et al. (2002) who reported that bunch weight increased with increasing rate of Papplication.

TABLE 2. The effect of fertigation and soil application of phosphorus on fruitfull buds and cluster weight of grape vine.

\begin{tabular}{|c|c|c|c|c|c|c|}
\hline \multirow{3}{*}{ Sources } & \multicolumn{3}{|c|}{ Fruitful buds (\%) } & \multicolumn{3}{|c|}{ Cluster weight(kg) } \\
\hline & \multicolumn{6}{|c|}{ Season 2011} \\
\hline & Rate 1 & Rate 2 & Mean & Rate 1 & Rate 2 & Mean \\
\hline TSP & 36.0 & 42.8 & 39.4 & 0.47 & 0.49 & 0.48 \\
\hline $\mathrm{H}_{3} \mathrm{PO}_{4}$ & 41.0 & 46.81 & 45.91 & 0.50 & 0.52 & 0.51 \\
\hline APP & 43.0 & 47.2 & 45.1 & 0.51 & 0.54 & 0.53 \\
\hline UP & 45.0 & 48.1 & 46.0 & 0.53 & 0.55 & 0.54 \\
\hline Mean & 41.3 & 46.23 & 43.60 & 0.50 & 0.53 & 0.52 \\
\hline \multicolumn{7}{|c|}{ L.S.D 0.05} \\
\hline Sources & \multicolumn{3}{|c|}{2.54} & \multicolumn{3}{|c|}{0.019} \\
\hline Rates & \multicolumn{3}{|c|}{1.31} & \multicolumn{3}{|c|}{0.012} \\
\hline \multicolumn{7}{|c|}{ Season 2012} \\
\hline TSP & 39.1 & 43.3 & 41.2 & 0.48 & 0.50 & 0.53 \\
\hline $\mathrm{H}_{3} \mathrm{PO}_{4}$ & 43.2 & 46.3 & 44.8 & 0.51 & 0.53 & 0.52 \\
\hline APP & 45.2 & 48.4 & 46.8 & 0.52 & 0.55 & 0.54 \\
\hline UP & 46.1 & 49.6 & 47.9 & 0.53 & 0.56 & 0.55 \\
\hline Mean & 43.4 & 46.9 & 45.2 & 0.51 & 0.54 & 0.54 \\
\hline \multicolumn{7}{|c|}{ L.S.D 0.05} \\
\hline Sources & \multicolumn{3}{|c|}{0.555} & \multicolumn{3}{|c|}{0.016} \\
\hline Rates & \multicolumn{3}{|c|}{1.01} & \multicolumn{3}{|c|}{0.021} \\
\hline
\end{tabular}

The results in Table 3 revealed that there is a significant difference between $\mathrm{P}$ ferigation and conventional $\mathrm{P}$ soil application on both berry weight and volume.. Also, the results showed that APP and UP produced largest berry weight and volume compared to the other P sources during the two seasons.

The results revealed that berry weight of Thompson seedless grapevine appeared heaviest with $\mathrm{P}$ rate of $40 \mathrm{~kg} \mathrm{P}_{2} \mathrm{O}_{5} \mathrm{Fed}^{-1}$. in both seasons. Whereas, in the first season the weight and volume of 100 berries increased from 154.9 to $156.8 \mathrm{gm} / 100$ berries and from 101.5 to $102.7\left(\mathrm{~cm}^{3}\right)$, respectively, and in the second season from 157.2 to $160 \mathrm{gm} / 100$ berries and from 103.3 to $105.5\left(\mathrm{~cm}^{3}\right)$, respectively. These results could be supported by those obtained by Dhillon et al. (1998) and Patil et al. (2008),who reported the weight that of 100 berries was increased by increasing the rate of $\mathrm{P}$-fertilizer application.

Egypt. J. Soil Sci. 56, No. 1 (2016) 
PHOSPHORUS FERTIGATION AND PREPLANT CONVENTIONAL SOIL... 45

TABLE 3. The effect of fertigation and soil application of phosphorus on berries weight and berries volume of grape vine.

\begin{tabular}{|c|c|c|c|c|c|c|}
\hline \multirow{3}{*}{ Sources } & \multicolumn{3}{|c|}{100 berries weight (gm) } & \multicolumn{3}{|c|}{100 berries volume $\left(\mathrm{cm}^{3}\right)$} \\
\hline & \multicolumn{6}{|c|}{ Season 2011} \\
\hline & Rate 1 & Rate 2 & Mean & Rate 1 & Rate 2 & Mean \\
\hline TSP & 147 & 150 & 148.5 & 97 & 99 & 98 \\
\hline $\mathrm{H}_{3} \mathrm{PO}_{4}$ & 153 & 156 & 154.5 & 101.7 & 102.3 & 102 \\
\hline APP & 159.7 & 160 & 159.8 & 103 & 104.3 & 103.7 \\
\hline UP & 159.7 & 161.3 & 160.5 & 104.3 & 105 & 104.7 \\
\hline Mean & 154.9 & 156.8 & 155.8 & 101.5 & 102.7 & 102.1 \\
\hline \multicolumn{7}{|c|}{ L.S.D 0.05} \\
\hline Sources & \multicolumn{3}{|c|}{1.34} & \multicolumn{3}{|c|}{1.36} \\
\hline Rates & \multicolumn{3}{|c|}{1.25} & \multicolumn{3}{|c|}{0.36} \\
\hline \multicolumn{7}{|c|}{ Season 2012} \\
\hline TSP & 150.0 & 153 & 151.5 & 98 & 102 & 100 \\
\hline $\mathrm{H}_{3} \mathrm{PO}_{4}$ & 156.5 & 160 & 158.3 & 104 & 106 & 105 \\
\hline APP & 161.2 & 163.1 & 162.2 & 105.3 & 107 & 106.2 \\
\hline UP & 160.9 & 163.9 & 162.9 & 106 & 107.1 & 106.6 \\
\hline Mean & 157.2 & 160 & 158.7 & 103.3 & 105.5 & 104.5 \\
\hline \multicolumn{7}{|c|}{ L.S.D 0.05} \\
\hline Sources & \multirow{2}{*}{\multicolumn{3}{|c|}{$\frac{2.99}{1.43}$}} & \multicolumn{3}{|c|}{1.76} \\
\hline Rates & & & & \multicolumn{3}{|c|}{1.26} \\
\hline
\end{tabular}

Also, these results are in conformity, with the findings of Sidhu et al., (2002) who reported that increasing $\mathrm{P}$ rate caused a significant increase in the volume of 100 berries in grape vine (vitis viniferal).

The results presented in Table 4 indicate that fertigation is superior when compared to the conventional soil application of triple super phosphate. Higher yield was obtained by fertigation technique. In this way, with every irrigation the fertilizer is placed in the soil volume in which roots are more active (Papadoulos, 1995).

As a-source of $\mathrm{P}$ fertigation, UP and APP gave the highest yield compared with $\mathrm{H}_{3} \mathrm{PO}_{3}$ and TSP (7.52 and 7.06 ) ton/fed,respectively, in the first season and in the second season (7.72 and 7.34ton/fed),respectively. This can be explained by the double acidification effect of UP. These results are in accordance to those obtained by Salem et al. (2004).

With regard to the application rate of $\mathrm{P}_{2} \mathrm{O}_{5}$ data revealed that $40 \mathrm{~kg} \mathrm{P}_{2} \mathrm{O}_{5}$ fed $^{-1}$ increased yield significantly than $20 \mathrm{~kg} \mathrm{P}_{2} \mathrm{O}_{5}$ fed $^{-1}$ in both seasons. results are in agreement with the findings obtained by Rakicevic et al., (2007).

\section{T.S.S. of grape vine}

The data presented in Fig. $1 \& 2$ indicated that the highest average of total soluble solid in both seasons was registered with fertigation as compared to the soil application of TSP. 
Table (4): The effect of fertigation and soil application of phosphorus on yield of grape vine.

\begin{tabular}{|c|c|c|c|c|c|c|}
\hline \multirow{3}{*}{ Sources } & \multicolumn{3}{|c|}{ Yield (kg/vine) } & \multicolumn{3}{|c|}{ Yield (Ton/fed) } \\
\hline & \multicolumn{6}{|c|}{ Season 2011} \\
\hline & Rate 1 & Rate 2 & Mean & Rate 1 & Rate 2 & Mean \\
\hline TSP & 7.28 & 8.40 & 7.84 & 6.55 & 7.56 & 7.06 \\
\hline $\mathrm{H}_{3} \mathrm{PO}_{4}$ & 7.76 & 8.95 & 8.36 & 6.98 & 8.06 & 7.52 \\
\hline APP & 8.08 & 9.32 & 8.70 & 7.27 & 8.39 & 7.83 \\
\hline UP & 8.31 & 9.53 & 8.83 & 7.48 & 8.58 & 8.03 \\
\hline Mean & 7.86 & 9.05 & 8.43 & 7.07 & 8.15 & 7.61 \\
\hline \multicolumn{7}{|c|}{ L.S.D 0.05} \\
\hline Sources & \multicolumn{3}{|c|}{0.316} & \multicolumn{3}{|c|}{0.052} \\
\hline Rates & \multicolumn{3}{|c|}{0.357} & \multicolumn{3}{|c|}{0.318} \\
\hline \multicolumn{7}{|c|}{ Season 2012} \\
\hline TSP & 7.58 & 8.71 & 8.15 & 6.82 & 7.84 & 7.34 \\
\hline $\mathrm{H}_{3} \mathrm{PO}_{4}$ & 7.99 & 9.15 & 8.57 & 7.19 & 8.24 & 7.72 \\
\hline APP & 8.34 & 9.55 & 8.95 & 7.50 & 8.60 & 8.05 \\
\hline UP & 8.59 & 9.89 & 9.22 & 7.73 & 8.90 & 8.32 \\
\hline Mean & 8.13 & 9.41 & 8.72 & 7.31 & 8.40 & 7.86 \\
\hline \multicolumn{7}{|c|}{ L.S.D 0.05} \\
\hline Sources & \multirow{2}{*}{\multicolumn{3}{|c|}{$\begin{array}{l}0.445 \\
0.298\end{array}$}} & \multicolumn{3}{|c|}{0.399} \\
\hline Rates & & & & \multicolumn{3}{|c|}{0.267} \\
\hline
\end{tabular}

The data also indicated APP gives the best measurable T.S.S, followed by UP, MAP and $\mathrm{H}_{3} \mathrm{PO}_{4}$ in the two growing seasons. Brito et al. (2000) observed that the least T.S.S was observed with $\mathrm{H}_{3} \mathrm{PO}_{4}$ treatment.

The data showed that the application rate of $40 \mathrm{~kg} \mathrm{P}_{2} \mathrm{O}_{5} \mathrm{fed}^{-1}$ was better than $20 \mathrm{~kg} \mathrm{P}_{2} \mathrm{O}_{5}$ fed $^{-1}$ in all treatments. Similar results were obtained by Salem et al. (2004) and Patil et al. (2008) who reported that raising P rate improved T.S.S in Thompson seedless grapevine.

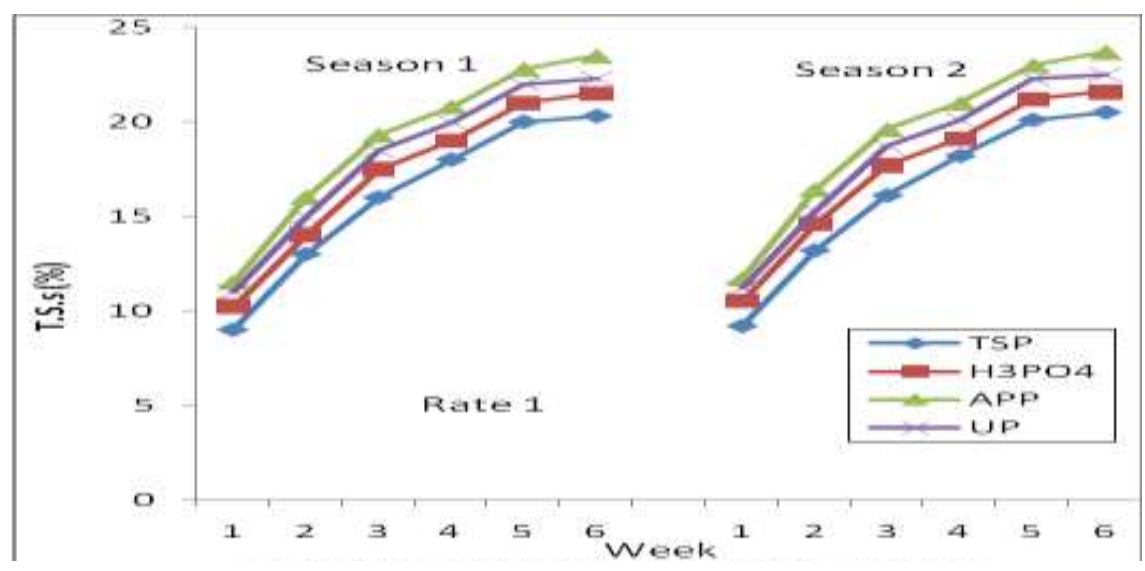

Fig 1. Effect of fertigation and soil application of phosphorus on T.S.S $(\%)$ of grapevine

Egypt. J. Soil Sci. 56, No. 1 (2016) 


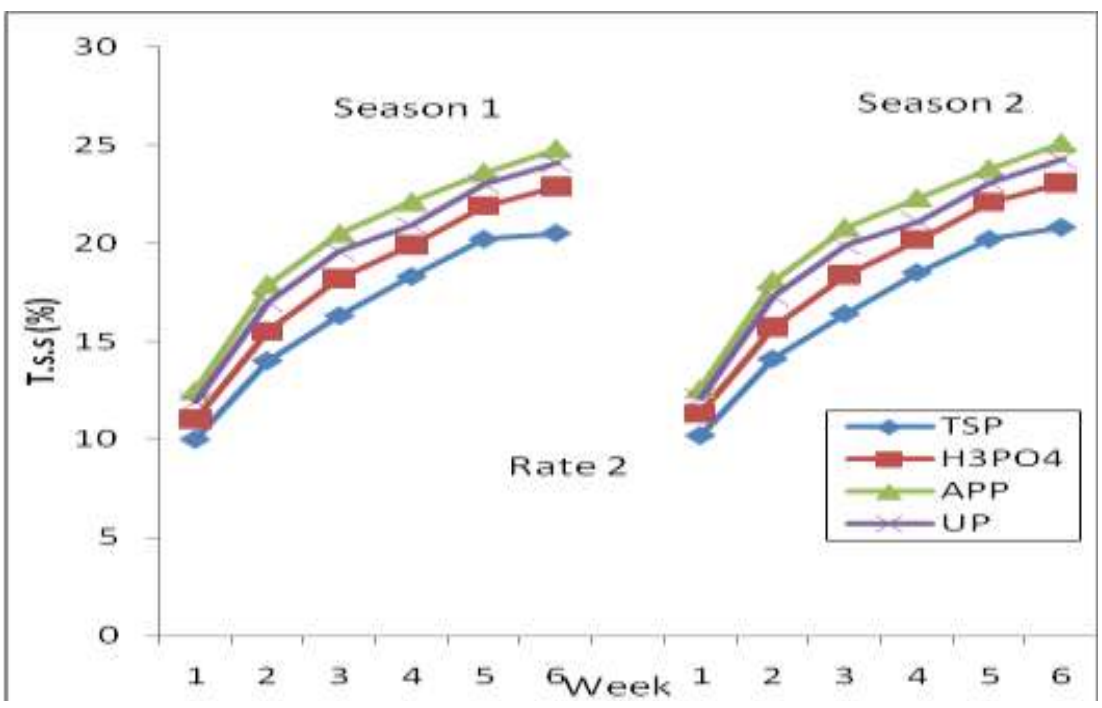

Fig 2. Effect of fertigation and soil application of phosphorus on T.S.S (\%) of grapevine

Phosphorus, Zn and Fe leaf petioles:

Data in Table 5 revealed that petiole $\mathrm{P}$ - concentration showed a significant difference between $\mathrm{P}$ fertigation and soil application by TSP in both seasons. APP and UP gave the highest values. These results were in agreement with Hagin et al., (2002) who reported a continuous $\mathrm{P}$ supply through fertigation techn que, may enhance $\mathrm{P}$ uptake later in the season and fertigation may creat a more favourable soil moisture condition that improves $\mathrm{P}$ mobility and availability.

Mohammed et al. (2004) revealed that in both seasons, phosphorus fertilizers use efficiency was higher with $\mathrm{P}$ fertigation than with conventional soil application.

Also, the petiol $\mathrm{Zn}$ and Fe concentrations were relatively higher under APP applications compared with other sources (Table 5). This result may be attributed to sequester $\mathrm{Fe}$ and $\mathrm{Zn}$ ions by the two adjacent hydroxyl group in various polyphosphate species, which increase their availability.

The results also indicated that $\mathrm{P}, \mathrm{Zn}$ and $\mathrm{Fe}$ concentration responded to increased phosphorus level from 20 to $40 \mathrm{~kg} \mathrm{P}_{2} \mathrm{O}_{5} / \mathrm{fed}$. This increase in the micronutrients concentration is similar to the findings of Dhillon et al. (1998).

\section{Phosphorus concentration in soil}

The available soil $\mathrm{P}$ concentration after fertilization significantly increased with TSP compared to P fertigation in the first week (Table 6). While, in the last week, the available soil $\mathrm{P}$ concentration significantly increased under $\mathrm{P}$ fertigation compared to the conventional application. 
TABLE 5. The effect of fertigation and soil application of phosphorus on leaf petioles $\mathrm{P}, \mathrm{Zn}$ and $\mathrm{Fe}$ concentrations of grape vine

\begin{tabular}{|c|c|c|c|c|c|c|c|c|c|}
\hline \multirow{3}{*}{ Sources } & \multicolumn{3}{|c|}{$\mathbf{P}(\%)$} & \multicolumn{3}{|c|}{ Zn (mg/kg) } & \multicolumn{3}{|c|}{ Fe (mg/kg) } \\
\hline & \multicolumn{9}{|c|}{ Season 2011} \\
\hline & Rate 1 & Rate 2 & Mean & Rate 1 & Rate 2 & Mean & Rate 1 & Rate 2 & Mean \\
\hline TSP & 0.22 & 0.24 & 0.23 & 28.1 & 30.3 & 29.2 & 122 & 125 & 123.5 \\
\hline $\mathrm{H}_{3} \mathrm{PO}_{4}$ & 0.26 & 0.29 & 0.28 & 28.5 & 30.9 & 29.70 & 124 & 128 & 126 \\
\hline APP & 0.28 & 0.30 & 0.29 & 29.3 & 31.1 & 30.2 & 125 & 129 & 127 \\
\hline UP & 0.28 & 0.29 & 0.29 & 29.1 & 31.0 & 30.1 & 125 & 127 & 126 \\
\hline Mean & 0.26 & 0.28 & 0.27 & 28.8 & 30.8 & 29.8 & 124 & 127.3 & 125.6 \\
\hline \multicolumn{10}{|c|}{ L.S.D 0.05} \\
\hline Sources & \multicolumn{3}{|c|}{0.013} & \multicolumn{3}{|c|}{0.843} & \multicolumn{3}{|c|}{3.46} \\
\hline Rates & \multicolumn{3}{|c|}{0.018} & \multicolumn{3}{|c|}{1.31} & \multicolumn{3}{|c|}{2.70} \\
\hline \multicolumn{10}{|c|}{ Season 2012} \\
\hline TSP & 0.24 & 0.27 & 0.26 & 29.0 & 31 & 30.0 & 123 & 126 & 124.5 \\
\hline $\mathrm{H}_{3} \mathrm{PO}_{4}$ & 0.26 & 0.29 & 0.28 & 29.4 & 31.7 & 30.6 & 124 & 128 & 126 \\
\hline APP & 0.29 & 0.32 & 0.31 & 29.6 & 31.9 & 30.8 & 126 & 129 & 127.5 \\
\hline UP & 0.28 & 0.30 & 0.29 & 29.5 & 31.7 & 30.6 & 125 & 128 & 126.5 \\
\hline Mean & 0.27 & 0.30 & 0.29 & 29.4 & 31.6 & 30.7 & 124.5 & 127.8 & 126.1 \\
\hline \multicolumn{10}{|c|}{ L.S.D 0.05} \\
\hline Sources & \multicolumn{3}{|c|}{0.024} & \multicolumn{3}{|c|}{0.681} & \multicolumn{3}{|c|}{1.80} \\
\hline Rates & \multicolumn{3}{|c|}{0.028} & \multicolumn{3}{|c|}{0.652} & \multicolumn{3}{|c|}{1.08} \\
\hline
\end{tabular}

TABLE 6. Phosphorus concentration ( $\mathrm{mg} / \mathrm{kg}$ soil) in soil after the first and the last week of fertilization.

\begin{tabular}{|c|c|c|c|c|c|c|}
\hline \multirow{3}{*}{ Sources } & \multicolumn{3}{|c|}{ After First week } & \multicolumn{3}{|c|}{ After Last week } \\
\hline & \multicolumn{6}{|c|}{ Season 2011} \\
\hline & Rate 1 & Rate 2 & Mean & Rate 1 & Rate 2 & Mean \\
\hline TSP & 9.12 & 11.31 & 10.26 & 11.30 & 12.87 & 12.09 \\
\hline $\mathrm{H}_{3} \mathrm{PO}_{4}$ & 8.18 & 10.33 & 9.26 & 11.96 & 13.65 & 12.81 \\
\hline APP & 8.40 & 10.45 & 9.42 & 11.93 & 13.96 & 12.95 \\
\hline UP & 8.42 & 10.41 & 9.42 & 11.83 & 13.96 & 12.90 \\
\hline Mean & 8.53 & 10.63 & 9.59 & 11.76 & 13.61 & 12.69 \\
\hline \multicolumn{7}{|c|}{ L.S.D 0.05} \\
\hline Sources & \multicolumn{3}{|c|}{0.125} & \multicolumn{3}{|c|}{0.097} \\
\hline Rates & \multicolumn{3}{|c|}{0.151} & \multicolumn{3}{|c|}{0.230} \\
\hline \multicolumn{7}{|c|}{ Season 2012} \\
\hline TSP & 9.25 & 11.54 & 10.40 & 12.26 & 13.48 & 12.87 \\
\hline $\mathrm{H}_{3} \mathrm{PO}_{4}$ & 8.38 & 10.61 & 9.50 & 12.86 & 14.33 & 13.60 \\
\hline APP & 8.57 & 10.63 & 9.60 & 12.91 & 14.54 & 13.73 \\
\hline UP & 8.45 & 10.55 & 9.5 & 12.82 & 14.61 & 13.72 \\
\hline Mean & 8.66 & 10.83 & 9.75 & 12.71 & 14.24 & 13.48 \\
\hline \multicolumn{7}{|c|}{ L.S.D 0.05} \\
\hline Sources & \multicolumn{3}{|c|}{0.236} & \multicolumn{3}{|c|}{0.212} \\
\hline Rates & \multicolumn{3}{|c|}{0.290} & \multicolumn{3}{|c|}{0.384} \\
\hline
\end{tabular}

These results were in agreement with Hagin and Tucker (1982) who reported that preplant conventional soil application of $\mathrm{P}$ has the advantage of providing the initial high $\mathrm{P}$ concentration in the soil solution. The data illustrated that there was insignificant difference between APP and UP in the first and the last week in both seasons. The soil $\mathrm{P}$ concentration after fertilization significantly increased with

Egypt. J. Soil Sci. 56, No. 1 (2016) 
PHOSPHORUS FERTIGATION AND PREPLANT CONVENTIONAL SOIL... 49

increasing $\mathrm{P}$ rate from 20 to $40 \mathrm{~kg} \mathrm{P}_{2} \mathrm{O}_{5} \mathrm{Fed}^{-1}$. This attribution is in agreement with Mohammed et al. (2004).

pH of Soil

The data presented in Table 7 indicated in both seasons, the soil $\mathrm{pH}$ under drippers decreased significantly under $\mathrm{P}$ fertigation compared to conventional application. This acidification was confirmed by earlier results of Treder (2005) and Howell \& Conradie (2012).

The data showed also that UP gave lower value of soil $\mathrm{pH}$ compared with $\mathrm{H}_{3} \mathrm{PO}_{4}$ and APP, which is confirmed by Papadopoulos, (2000).

TABLE 7. The effect of fertigation and soil application of phosphorus on soil $\mathrm{pH}$ after the last week fertilization.

\begin{tabular}{|l|c|c|c|c|}
\hline \multirow{2}{*}{ Sources } & \multicolumn{4}{|c|}{ pH } \\
\cline { 2 - 5 } & \multicolumn{2}{|c|}{ Season 2011 } & \multicolumn{2}{c|}{ Season 2012 } \\
\cline { 2 - 5 } & Rate 1 & Rate 2 & Rate 1 & Rate 2 \\
\hline $\mathrm{TSP}$ & 8.18 & 8.13 & 8.16 & 8.11 \\
\hline $\mathrm{H}_{3} \mathrm{PO}_{4}$ & 8.09 & 8.02 & 8.06 & 8.01 \\
\hline $\mathrm{APP}$ & 8.06 & 8.00 & 8.05 & 7.97 \\
\hline UP & 8.03 & 7.96 & 8.01 & 7.93 \\
\hline Mean & 8.09 & 8.03 & 8.07 & 8.01 \\
\hline L.S.D 0.05 & \multicolumn{5}{|l|}{} \\
\hline Sources & 0.018 & 0.025 & \\
\hline Rates & 0.006 & 0.016 & \\
\hline
\end{tabular}

Urea under drip irrigation, urea phosphate is rapidly hydrolysed in the soil to ammonium and then oxidized to nitrate.

As regards to $\mathrm{P}$ rates, the data showed that the soil $\mathrm{pH}$ significantly decreased at the highest $\mathrm{P}$ fertilization rate which is in agreement with Mohammad et al., (2004).

\section{References}

A.O.A.C., (1990) Official Methods Of Analysis Association Of Official Analytical Chemists, $15^{\text {th }}$ ed Inc Wash D.C.

Ahmed, A. (1991) The effect of N, P and K Soil and Foliar Treatments on Buds Behavior and Some Vegetative and Fruiting Characteristics of White Banaty Seedless Grapevines. M.Sc. Thesis, Fac. Agric., Minia Univ., 136P.

Bravdo, B.A. (2007) Effect of irrigation and fertilization on fruit and wine quality. Acta Horticulturae, 754, 265-274.

Brito, L.T., Soares, J.M., Faria, C.M. and Costa, N.D. (2000) Sources of phosphorus applied through fertigation in muskmelon. Revista Brasileira Engenharia Agricola Ambien-Tal, 4 (1), 19-22. 
Cottenie, A., M. Verlo, M. Kicken, Velghe, G. and Camerlynch, R. (1982) Chemical Analysis of Plant and Soil, Laboratory of Agro-Chemistry. State Univ. Gent, Belgium.

Dhillon, W.S.; Bindra, A.S. and Brar, B.S. (1998) Response of grapes to phosphorus fertilizer on yield, quality and nutrient status. Journal of the Indian Society of Soil Science, 46 (4), 633-656.

Gomez, J. and Gomez, A.A. (1984) Statistical Procedures for Agricultural Research. John Wiley and Sons , New York, $2^{\text {nd }}$ ed.,68p.

Hagin, J. and Tuker, B. (1982) Fertilization of Dry Land and Irrigated Soils. SpringerVerlag. Berlin Heidelberg. New York.

Hagin, J.; Sneh, M. and Lowengart-Aycicegi, A. (2002) Fertigation: Fertilization through irrigation. International Potash Institute, Basel, Switzerland,22p.

Howell, C.L. and Conradie, W.J. (2012) Comparison of three different fertigation strategies for drip irrigated table grapes-Part II. Soil and Grapevine Nutrient. S. Afr. J. Enol. Vitic., 34, (1), 10-18.

Howell, C.L. and Conradie, W.J. (2013) Comparison of three different fertigation strategies for drip irrigated table grapes-part II. Soil and grapevine nutrient status S.Afr. J. Enol. Vitic, 34 (1), 10-20.

Jagdev, S.; Upadhyay, A.K. Shikhamany. S.D. and Singh, R.K. (2008) Effect of fertilizer application through irrigation water on Thompson seedless grape yield and fertilizer use efficiency. Acta Horticulture; (785), 399-408.

Klute, A. (1986) "Method of Soil Analysis". Part 1, 2n , Am Soc. Agron. Inc., Soil Sci. Soc. Am., Madison, Wisconsin USA.

Mohammad, M.J, Hammouri, A. and Ferdows, A.E. (2004) Phosphorus fertigation and preplant conventional soil application of drip irrigated summer squash. Journal of Agronomy, 3 (3), 162-169.

Olsen, S.R.; Cole, C.W. Wantanabe, F.S. and Dean, L.A. (1958) Estimation of available phosphorus in soil by extraction with sodium bicarbonate. U.S. Dept. Agric., Circular No. 930, 1-19.

Papadoulos, I. (1995) Use of labeled fertilizers in fertigation research. Proceedings "International symposium on Nuclear and Related Techniques in Soil/Plant Studies on Sustainable Agriculture and Environmental Preservation",Vienna, 17-21 October, 1994: 399-410.

Papadopoulos, I. and Ristimaki, Leena, M. (2000) Nitrogen and Phosphorous fertigation of tomato and eggplant. Acta Horticultural (511), 73-79.

Patil, D.R.; G.S. Sulikeri; H.B. Patil and R.A. Balikai, (2008) Studies on the integrated nutrient management in Thompson seedless grapes. Acta Horticulturea, 785, 383387.

Egypt. J. Soil Sci. 56, No. 1 (2016) 
PHOSPHORUS FERTIGATION AND PREPLANT CONVENTIONAL SOIL... 51

Rakicevic, M.; Ogasanovic, D. Mitrovic, M. Blagojevic, M. and Stajic, Z.K. (2007) The effect of plant density and rate of fertilizers on yield and fruit size of plum cultivar (Cacanska lepotica) Acta Horticulturae, 734, 401-405.

Salem, A.T., Kilany, A.E. and Shaker, G.S. (2004) The influence of NPK, phosphorus source and potassium foliar application on growth and fruit quality of Thompson seedless grapevines. Acta Horticultural 640, 163-173.

Sidhu, A.S., Tomer, N.S. Chahil, B.S. and Brar, J.S. (2002) Effect of N, P and K on Physicochemical Characteristics of grapes (Vitis Vinifera L.) during development. Haryana J. Hort. Sci., 31 (1/2), 19-22.

Treder, W., (2005) Variation in soil $\mathrm{pH}$, Calcium and magnesium states influenced by drip irrigation and fertigation. J. Fruit Ornam. Plant Res., 13, 59-70.

( Received 29/3/2015; accepted $9 / 9 / 2015)$

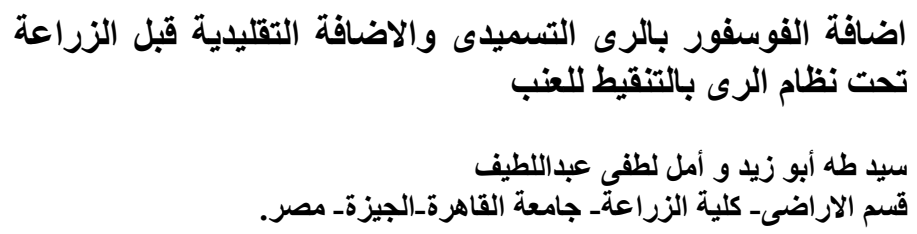

أقيمت تجربة حقلية لمدة موسمين متعاقبين (2011-2012) وذللك لمقارنة استجابة

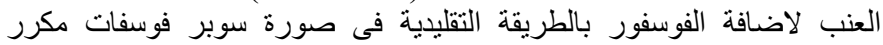

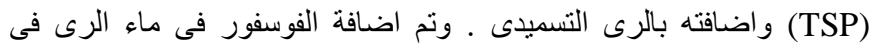

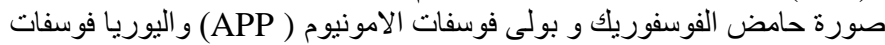
وذللك بمعدلين من الفوسفور هما(20،40) كجم

ونت أخذ عينات نباتية وعينات من التربة وذلك لتحليلها ــ وأوضحت

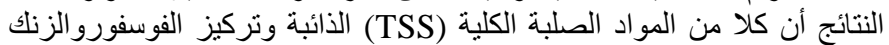

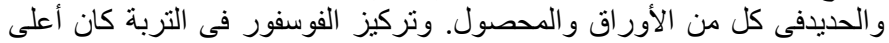

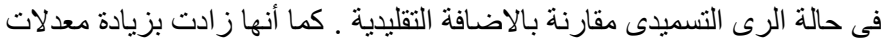

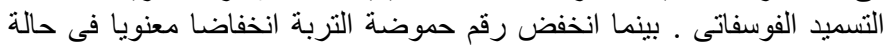

الرى التسميدى وذللك مقارنة بالاضافة التقليدية .

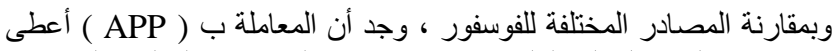

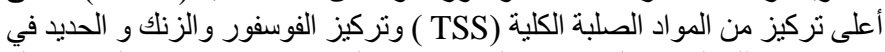

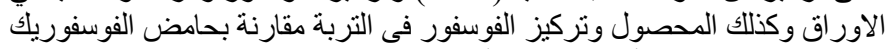

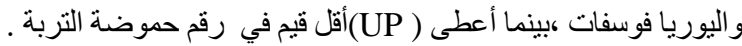

